Dying Modern 

๑รัด -

\section{Dying Modern}

a meditation on elegy

\section{Diana Fuss}

Duke University Press

Durham and London 
(C) 2013

Duke University Press

All rights reserved

Printed in the United

States of America on

acid-free paper @

Designed by

C. H. Westmoreland

Typeset in Whitman

by Tseng Information

Systems, Inc.

Duke University Press

gratefully acknowledges

the Princeton University

Department of English,

which provided funds

toward the publication

of this book.
Library of Congress

Cataloging-in-Publication Data

Fuss, Diana

Dying modern : a meditation on elegy /

Diana Fuss.

$\mathrm{p} \mathrm{cm}$

Includes bibliographical references.

IS BN 978-o-8223-5375-1 (cloth : alk. paper)

IS BN 978-o-8223-5389-8 (pbk. : alk. paper)

1. Elegiac poetry, American-History and

criticism. 2. Elegiac poetry, English-History

and criticism. 3. Poetry, Modern-History and

criticism. 4. Death in literature. I.Title.

PS309.E4F87 2013

$811.009^{\prime} 3548-\mathrm{dc}^{2} 3$

2013003132

See pages $149-50$ (which are considered an extension of this page) for additional copyright information. 


\section{FOR MY BROTHERS}

Jim, who travels abroad Dave, who nests at home Dan, who joins me here AND Tom, who got there first 
